\title{
(息)
}

Citation:

Killick, D (2018) Graduates in/for a multicultural and globalising world. On the Horizon, 26 (2). pp. 72-78. ISSN 1074-8121 DOI: https://doi.org/10.1108/OTH-10-2017-0084

Link to Leeds Beckett Repository record:

https://eprints.leedsbeckett.ac.uk/id/eprint/5920/

Document Version:

Article (Accepted Version)

The aim of the Leeds Beckett Repository is to provide open access to our research, as required by funder policies and permitted by publishers and copyright law.

The Leeds Beckett repository holds a wide range of publications, each of which has been checked for copyright and the relevant embargo period has been applied by the Research Services team.

We operate on a standard take-down policy. If you are the author or publisher of an output and you would like it removed from the repository, please contact us and we will investigate on a case-by-case basis.

Each thesis in the repository has been cleared where necessary by the author for third party copyright. If you would like a thesis to be removed from the repository or believe there is an issue with copyright, please contact us on openaccess@leedsbeckett.ac.uk and we will investigate on a case-by-case basis. 


\section{Graduates in/for a multicultural and globalising world}

\begin{tabular}{|r|l|}
\hline Journal: & On The Horizon \\
\hline Manuscript ID & Draft \\
\hline Manuscript Type: & Practitioner Paper \\
\hline Keywords: & $\begin{array}{l}\text { Global citizen, selfhood, multicultural education, internationalisation, higher } \\
\text { education }\end{array}$ \\
\hline \multicolumn{2}{|l}{} \\
\hline
\end{tabular}

\section{SCHOLARONE \\ Manuscripts}




\section{Graduates in/for a multicultural and globalising world}

\section{From theory}

\section{Global citizenship \& global selves}

John Dewey (Dewey, 1916/2012, 2006) argued for an education for democracy, Paulo Freire that it should be for freedom through the development of critical consciousness (Freire \& Faundez, 1989; Freire, 1998). The globalising world enlarges the scope of their visions, and of the role that an internationalising higher education can play to secure individual freedoms across cultures, geographies, and communities - locally and globally. I propose a global graduate to be someone who has the capabilities to lead a life she has reason to value in a multicultural and globalising world. This definition owes much to the capability work of Amatya Sen (Sen, 1999, 2008), and situates all our graduates as people who live in a culturally diverse world in which, gender, ethnicity, nationality, social class, and many other dimensions of difference materially impact upon an individual's freedoms to conduct his life in ways which will give him reason to value it. University education makes a difference to what I refer to as an individual's subjective capabilities for leading such a life, and today as never before, those capabilities need to be relevant to and applicable within a world in which encounters with diverse others are increasingly commonplace and often contested, and where the impacts we have upon the lives of diverse others are increasingly globally as well as locally dispersed.

Leading a life she has reason to value implies that a graduate's life stands up to scrutiny, that she has reflected upon it, has drawn evidence of its value from how others also see the ways in which she leads that life. Unlike many framings of the global citizen, this does not call for any specific kinds of active participation (Dower, 2003; Kubow et al., 2000; Schattle, 2009); active participation requirements are untenable in a world where the capacity for any individual to act are circumscribed by the freedoms afforded by, for example, the intersections (Crenshaw, 1991)of his society, material wealth, race, and gender.

A second difficulty with many framings of global citizenship is a tendency to focus upon the international impacts of lives (professions, industries, consumption), which neglects to acknowledge value in more local impacts. Citizenship may not end at home, but it has a place there. A person leading a life she has reason to value in a multicultural and globalising world embraces both the local and the international parameters of scrutiny, and the communities and contexts within which to base her evidence for critical self-reflection.

Where discourse around global citizenship has emphasized global perspectives and competencies rather than its civic dimensions (Caruana, 2007), there remain other difficulties with the term 'global citizen': it has been appropriated by all manner of causes to describe all manner of ways of being (Urry, 2000, 2003); for some, it implies a viable system of global governance, human rights, or rule of 
law (Anker, 2002); it is an empty signifier in contexts where 'citizenship' confers limited or differential rights to 'citizens' who belong to different minority groups; it is apparently not open to individuals whose nation is at war (Noddings, 2005); and, most importantly I suggest, it focuses attention on a specific performance of the self-as-citizen - and so it is somewhat reductive. How about the self-asemployee or -employer, self-as-parent, self-as-tourist, self-as-romantic, or selfas-activist? To lead a life she has reason to value, requires a sense of self-in-theworld which transcends mere citizenship. Selfhood is a matter of identity, it is the embodiment of how I stand before myself in the world, among others. Self-inthe-world identity is rooted in an ethic and a sensibility which says that 'we are all equally human', and it is realised in acknowledgements which have their genesis in how we identify ourselves among diverse others. Illustrative examples would be:

I am the kind of person who...

- seeks to engage with others in ways which allow them the freedoms to lead lives they have reason to value;

- is inclined to find ways of being which do not depend upon limiting the freedoms of others to lead lives they have reason to value; and

- accepts that the ways in which I choose to conduct my life are not always the ways others choose to conduct their lives;

For these reasons, I suggest that universities should be concerned to provide learning and teaching experiences through which students develop dimensions of their identities which will enable them to become global selves, rather than, merely, global citizens, capable of leading lives they each have reason to value, given the freedoms they are afforded or denied, in the local and global contexts of a multicultural and globalising world.

Generically, we can propose two related sets of subjective capabilities which a graduate who identifies her self-in-the-world along the lines indicated above will need (for a detailed curriculum review guidnace document, see Killick, 2006):

1. Global perspective capabilities to recognise the ways in which her own personal and professional actions, and those of others, impact upon the capabilities of diverse people in diverse contexts to lead lives they have reason to value.

2. Cross-cultural capabilities to conduct her personal and professional life among diverse people in diverse contexts in ways which do no harm to their capabilities to lead lives they have reason to value.

\section{Global perspective capabilities}

To recognise how others experience the world is at essence a matter of empathy. This may be misunderstood to mean something like 'understanding how I would feel in her shoes', when what is really needed is more like 'understanding how she feels in her shoes'. Being mindful, and reflecting upon 'how this act enhances or diminishes her capabilities to lead a life she has reason to value.' This is akin 
to adopting an emic perspective (Headland et al., 1990) as employed in anthropology, or making isomorphic attributions (Triandis, 1994) in crosscultural psychology. It requires understandings of human lives which recognise the inadequacy of measuring them simply by economic value or by juxtaposing them against 'our' values. An action might enhance the economic circumstances of an individual but if, in so doing, it robs her of something else - an aspect of social community, a symbol of moral value, a sense of personal worth - it risks, on balance, reducing her capability to lead a life she has reason to value. A global perspective requires:

- knowledge of some of the ways of the world, of how cultures large and small give different shapes to what brings people joy and sorrow, of how actions here can impact lives there;

- dispositions to apply that knowledge, a will to bring it to bear when acting in the world in whatever ways are open to me;

- skills to critique information and reflect upon meanings; and

- emotional intelligence within which empathy can flourish.

\section{Cross-cultural capabilities}

Human beings tend to live in communities, and have built communities of many varieties in many contexts. This attests to the human capacity to live with others, and to do so in diverse contexts. However, it seems that coming together in community leads us to favour the ways in which that particular community enacts its ways of being together, and the social structures which in some ways demarcate the 'best' way of being. Once established, our communities tend not to encourage deviation from their self-created norms. Self-identity is wrapped up in community, and in the rituals of community, and possibly also in the values of community - though I have some doubts concerning just how widely fundamental human values themselves do actually differ across most communities. Cross-cultural capability requires:

- knowledge about the mundane ways in which cultures are enacted and communicated;

- dispositions to bring that knowledge to bear to ease the flow of intercultural encounters and communications;

- skills to monitor and modify one's own behaviours in order to ease those same flows; and

- emotional intelligence within which resilience and self-efficacy can flourish.

\section{To practice}

The practice of learning and teaching in higher education is not the only arena for the development of global-self capabilities, but for those who are privileged to attend university, it is a significant one. As illustrated above, required capabilities span learning dimensions, demanding attention to the building of knowledge, dispositions, skills, and emotional intelligence. Important aspects within learning and teaching practice for the development of global selfhood are the degrees to which: 
- the learning environment is designed to reflect and promote principles of academic equity;

- the formal curriculum is designed to develop cross-cultural capability and global perspectives; and

- learning activities are designed to enable students to engage in equitable, intercultural experiences and reciprocal learning.

Space restrictions allow only a brief consideration of each of these, but all are needed, and as indicated, all need design. There is ample evidence that simply bringing together diverse students, whether internationally or locally, does little to promote mutual learning, and when conditions for intercultural contact are unequal, competitive, or lacking in authority-support, they may even advance stereotyping and prejudice (Allport, 1979/1954; Pettigrew \& Tropp, 2008). Education risks devaluing and destroying the cultural integrity of students from minority groups by a recognition, only, of the validity of majority values and perspectives (Ladson-Billings, 1995, 2013). For diversity to bring about the kinds of learning gain which will develop global selves without diminishing local identities, each of these dimensions of practice needs to be designed, and critically reviewed, for that end.

\section{Learning environments}

All learning environments - on-line, face-to-face, local, international - are populated by diverse students and diverse faculty. The parameters of that diversity vary by context, and shift over time. Current activities in internationalizing higher education are adding to student and faculty diversity, and to the range of national and cultural contexts in which even a single program might be delivered and experienced. Whether a particular cohort, campus, or institution is diverse across multiple dimensions, or 'only' with regard to students' preferred approaches to learning and prior educational experience, designing it to neither advantage nor disadvantage any individual or group of students is the foundational principle of academic equity. Students and faculty are the most significant elements of a learning environment; how they envision and engage with their diverse peers and students is the largest factor in determining the degree to which that environment is inclusive. Environments in which some people are excluded, segregated, discriminated against, or set within a deficit model cannot support equitable learning and teaching practice. Nor can they create the conditions in which encounters between diverse students or students and faculty build either self-efficacy or empathy.

When thinking of an equitable and inclusive learning environment which promotes capabilities for a multicultural and globalising world, some of the particular design considerations are:

- diverse, majority and minority, voices are sought out, heard, and critiqued at all levels and in all forums and functions of the organisation;

- media displayed in any format and context represents a wide variety of diverse others in non-tokenistic ways, which do not demean or pander to stereotypes; 
- learning spaces and non-learning spaces are, and feel, safe, accessible, welcoming, and empowering for all;

- any form of non-inclusive behaviour is challenged and seen to be challengeable;

- the institution is transparent about is business practices, and evidences how it takes corporate social responsibility along with local and global stakeholder impact seriously across its activities.

These are not small considerations, and are always likely to need continuous attention, but institutions which call for their students to work towards global selfhood need to evidence that they are similarly striving to embody the same capabilities. The learning environments which they create inhibit or enable global selfhood learning; they are not neutral spaces; their messages cannot be left to chance.

\section{Formal Curriculum}

In this context, formal curriculum refers to that which is set down within course, module, or program documentation as the intended learning outcomes and content upon which a student will be assessed. Although many students enjoy freedoms with regard to modules or courses which might contribute to their full program of study, required elements within their programs, the 'mainstream curriculum', really define what it is to be a student of BA $x$ rather than BSc $y$. Effective practice in curriculum design, means that outcomes associated with global selfhood are required, and assessed elements within the mainstream curriculum. Otherwise they carry less import, risk being seen as peripheral to the discipline, and may be 'escapable'. Perhaps radically, this practice model requires that students who do not develop global selfhood capabilities are unfit to graduate.

This is a weighty proposition. But the capabilities of those who are privileged to graduate from higher education, who become professionals, leaders, influencers, parents, role models, and citizens in a multicultural and globalising world is a weighty matter.

In such a model, the design of the mainstream curriculum and its assessment does not confine itself to disciplinary skills and knowledge, but seeks to be personally transformative. It deliberately and systematically:

- embeds the capabilities of the global graduate within disciplinary learning outcomes;

- incorporates and critiques diverse disciplinary perspectives, models, practices, and their impacts upon different peoples in different contexts; and it does so attentive to the dangers of domination by those of majority groups;

- enables students to communicate with and dwell among peoples whose norms, rituals, beliefs and practices do not accord with their own;

- builds a sense of identity, self-efficacy, and emotional intelligence which underpin the willingness and the inclination to engage with the challenges 
associated with working with others to find common ground and workable solutions.

\section{Learning Activities}

Learning activities can be thought of as the interaction space in which the formal curriculum meets the learning environment. The practice of building inclusive and equitable learning environments aligns with the practice of designing curriculum to build global graduate capabilities through the creation of learning activities within which all students can engage with each other and their learning equitably. Activities which facilitate and reward such ways of being include those in which students:

- collaborate rather than compete;

- are situated as expert informants;

- take responsibility for their learning process;

- take responsibility for their communications \& interactions with peers;

- critique disciplinary knowledge and practice from alternative perspectives;

- recognise own perspectives as limited and limiting; and

- dismantle structures which give groups or individuals differential prestige or power.

Bringing students from diverse cultures, locally and internationally, into interactive learning activities is a significant social act. The educational outcomes of that act extend far beyond learning about the discipline. This is inescapable, and to neglect to design those activities in ways which will enhance the capabilities of all students to live lives they have reason to value within a multicultural and globalising world is irresponsible.

\section{Faculty development}

Learning and teaching practice is designed and delivered by faculty. Building practice in which global selfhood is an identified graduate outcome within the mainstream curriculum depends upon faculty believing in its legitimacy and having the capabilities to develop and sustain learning environments, curricula, and activities which are aligned towards that end. University policies and faculty development programmes are necessary to motivate, recognise and reward, and support faculty in this work. Current developments within internationalisation are creating new opportunities for international and intercultural student learning partnerships, for global and local collaborative projects, and for building reciprocal learning communities for diversely situated students. They are opening similar opportunities for the academic community. The landscapes of academic practice (Wenger-Trayner \& Wenger-Trayner, 2015) are newly complex, situating faculty at times as experts and at other times as novices as they traverse physical and virtual learning communities and contexts. Faculty cannot secure global selfhood for their students unless they are able to anchor their own identities and practice within the same frame. This requires a new understanding of the role and the scope of faculty development (Killick, 2015, 
2018) if it is to build faculty capabilities to also lead lives they have reason to value in their tumultuous multicultural and globalising worlds.

Although this discussion has been principally situated in the contexts of internationalisation, it has direct relevance to diversity and multicultural education. Significant progress could be made by meaningful collaboration across the expertise within each of these fields (Killick, 2017; Olson et al., 2007).

\section{References}

Allport, G. (1979/1954). The Nature of Prejudice. Cambridge, MA: Perseus Books. Anker, Christien van der. (2002). Global Justice, Global Institutions and Global Citizenship. In Global Citizenship: A Critical Reader, eds N. Dower \& J. Williams, 158-168. Edinburgh: Edinburgh University Press.

Caruana, V. (2007). Internationalisation of HE in the UK: 'Where are we now and where might we go?'. Paper presented at the Education in a Changing Environment Conference, Salford.

Crenshaw, W. (1991). Mapping the margins: Intersectionality, identity, politics, and violence against women of color. Stanford Law Review, 43(6), 12411299.

Dewey, J. (1916/2012). Democracy and Education: Start Publishing LLC. Kindle ebook edition.

Dewey, J. (2006). The Democratic Conception in Education. In Education, Globalization \& Social Change, eds. H. Lauder, P. Brown, J.-A. Dillabough \& A. H. Halsey, 91-100. Oxford: Oxford University Press.

Dower, N. (2003). An Introduction to Global Citizenship. Edinburgh: Edinburgh University Press.

Freire, P, \& Faundez, A. (1989). Learning to question: A pedagogy of liberation. New York: Continuum.

Freire, Paulo. (1998). Pedagogy of Freedon: Ethics, Democracy and Civic Courage. Lanham: Rowman and Littlefield.

Headland, T. N, Pike, K.L, \& Harris, M (Eds.). (1990). Emics and Etics: the insider/ outsider debate. Newbury PArk, CA: Sage.

Killick, D. (2006). Cross-Cultural Capability \& Global Perspectives. Guidelines for Curriculum Review. http://eprints.leedsbeckett.ac.uk/2808/.Accessed October 2017.

Killick, D. (2015). Internationalisation and the academic developer. Educational Developments, 16(3), 1-6.

Killick, D. (2017). Internationalization and Diversity in Higher Education. London: Palgrave.

Killick, D. (2018). Developing Intercultural Practice: Academic Development in a Multicultural and Globalizing World. Abingdon: Routledge.

Kubow, Patricia, Grossman, David, \& Ninomiya, Skira. (2000). Multidimensional citizenship: Educational policy for the 21st Century. In Citizenship for the 21st Century: An International Perspective on Education, eds. J. J. Cogan \& R. Derricott, 131-150. London: Kogan Page.

Ladson-Billings, G. (1995). Toward a theory of culturally relevant pedagogy. American Educational Research Journal, 32(3), 465-491. 
Ladson-Billings, G. (2013). Critical race theory - what it is not! In M. Lynn \& A. D. Dixon (Eds.), Handbook of Critical Race Theory in Education (pp. 34-47). Abingdon: Routledge.

Noddings, N. (2005). Global citizenship: promises and problems. In Educating Citizens for Global Awareness, ed. N. Noddings, 1-21. New York, NY: Teachers College, Columbia University.

Olson, C.L, Evans, R, \& Shoenberg, R.F. (2007). At Home in the World: Bridging the Gap Between Internationalization and Multicultural Education. Washington, DC: American Council on Education.

Pettigrew, T.F, \& Tropp, L.R. (2008). How does intergroup contact reduce prejudice? Meta-analytic tests of three mediators. European Journal of Social Psychology, 3, 922-934.

Schattle, Hans. (2009). Global citizenship in theory and practice. In The Handbook of Practice \& Research in Study Abroad, ed. R. Lewin, 3-20. Abingdon: Routledge.

Sen, A. (1999). Development as Freedom. Oxford: Oxford University Press.

Sen, A. (2008). The idea of justice. Journal of Human Development, 9(3), 331-342.

Triandis, H.C. (1994). Culture and Social Behavior. New York, NY: McGraw-Hill.

Urry, J. (2000). Sociology beyond Societies: Mobilities for the twenty-first century. London: Routledge.

Urry, J. (2003). Globalisation and Citizenship. http://www.lancaster.ac.uk/fass/resources/sociology-onlinepapers/papers/urry-globalisation-and-citizenship.pdf. Accessed October 2017.

Wenger-Trayner, E, \& Wenger-Trayner, B. (2015). Learning in a landscape of practice. A framework. In Learning in Landscapes of Practice. Boundaries, identity, and knowledgeability in practice-based learning, eds. E. WengerTrayer, M. Fenton-O'Creevy, S. Hutchinson, C. Kubiak \& B. Wenger-Trayer, 13-29. Abingdon: Routledge. 